\title{
Price Competition in Procurement
}

by J.M. Keisler and W.A. Buehring

Decision and Information Sciences Division,

Argonne National Laboratory, 9700 South Cass Avenue, Argonne, lllinois 60439

July 1996

Work sponsored by U.S. Department of Energy, Office of Waste Management 
बतy

This report is printed on recycled paper. 


\section{DISCLAIMER}

Portions of this document may be illegible in electronic image products. Images are produced from the best available original document. 


\section{DISCLAIMER}

This report was prepared as an account of work sponsored by an agency of the United States Government. Neither the United States Government nor any agency thereof, nor any of their employees, makes any warranty, express or implied, or assumes any legal liability or responsibility for the accuracy, completeness, or usefulness of any information, apparatus, product, or process disclosed, or represents that its use would not infringe privately owned rights. Reference herein to any specific commercial product, process, or service by trade name, trademark, manufacturer, or otherwise does not necessarily constitute or imply its endorsement, recommendation, or favoring by the United States Government or any agency thereof. The views and opinions of authors expressed herein do not necessarily state or reflect those of the United States Government or any agency thereof. 


\section{CONTENTS}

ACKNOWLEDGMENTS

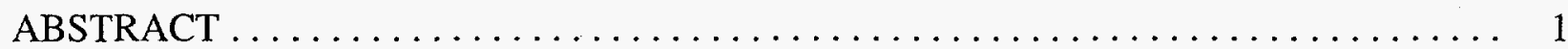

$1 \quad$ INTRODUCTION $\ldots \ldots \ldots \ldots \ldots \ldots \ldots \ldots \ldots \ldots \ldots \ldots \ldots \ldots \ldots \ldots$

1.1 Government Agencies and Competitive Bidding $\ldots \ldots \ldots \ldots \ldots \ldots \ldots \ldots \ldots$

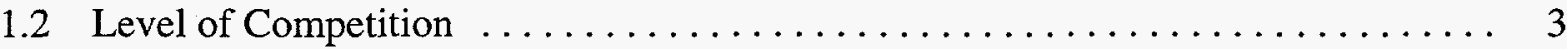

2 THEORETICAL BACKGROUND $\ldots \ldots \ldots \ldots \ldots \ldots \ldots \ldots \ldots \ldots \ldots \ldots \ldots$

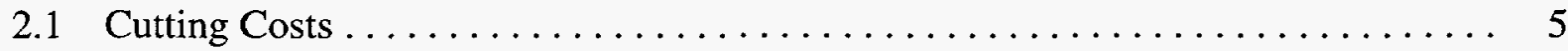

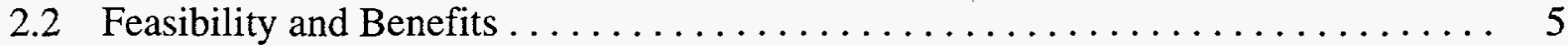

2.3 Data on the Benefits of Competition $\ldots \ldots \ldots \ldots \ldots \ldots \ldots \ldots \ldots \ldots$

2.4 Summary of Theoretical and Empirical Literature $\ldots \ldots \ldots \ldots \ldots \ldots \ldots$

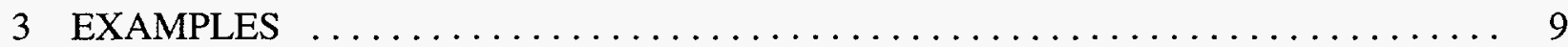

$3.1 \quad$ Base Case $\ldots \ldots \ldots \ldots \ldots \ldots \ldots \ldots \ldots \ldots \ldots \ldots \ldots \ldots \ldots \ldots \ldots$

3.2 Operating the Competition Model in the Base Case $\ldots \ldots \ldots \ldots \ldots \ldots \ldots \ldots 11$

3.3 Equilibrium Prices and Their Relevance $\ldots \ldots \ldots \ldots \ldots \ldots \ldots \ldots \ldots \ldots \ldots$

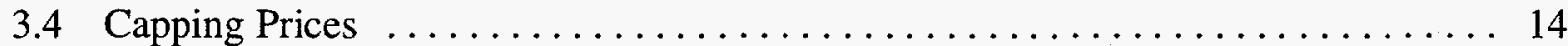

3.5 Base Case plus Intense Competition $\ldots \ldots \ldots \ldots \ldots \ldots \ldots \ldots \ldots \ldots \ldots$

4 EXPLORATORY EXAMPLES FOR SPECIFIC FACTORS $\ldots \ldots \ldots \ldots \ldots \ldots \ldots$

4.1 Government Payments and the Number of Vendors $\ldots \ldots \ldots \ldots \ldots \ldots \ldots$

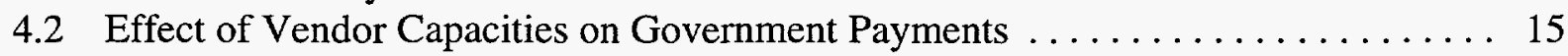

4.3 Effect of Buyer's Sensitivity and Price on Payments $\ldots \ldots \ldots \ldots \ldots \ldots \ldots \ldots \ldots$

4.4 Effect of Proportion of Fixed-to-Variable Costs on Pricing . . . . . . . . . . . . 18

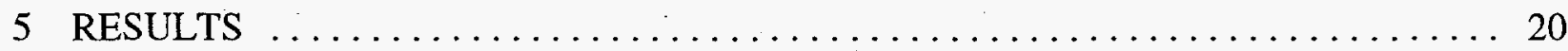

5.1 Limitations on the Interpretation of Results $\ldots \ldots \ldots \ldots \ldots \ldots \ldots \ldots \ldots$

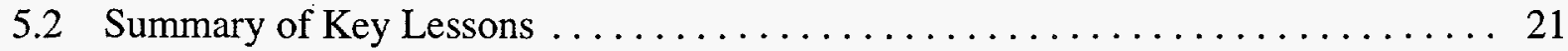

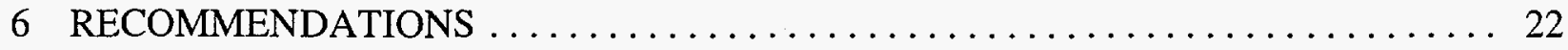

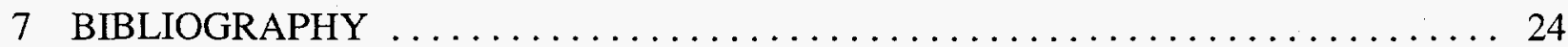




\section{TABLES}

1a Factors Relating to Benefits of Market Solution $\ldots \ldots \ldots \ldots \ldots \ldots \ldots \ldots$

$1 \mathrm{~b}$ Factors Relating to Risk of Collusion $\ldots \ldots \ldots \ldots \ldots \ldots \ldots \ldots \ldots \ldots$

1c Factors Favoring Private Contractor vs. Government Control ............... 7

2 Empirical Data on the Benefits of Competitive Procurement $\ldots \ldots \ldots \ldots \ldots \ldots$

3 Predicted Government Payments Compared with the Number of Vendors . . . . . . . . 15

4 Relation of Predicted Payments to Vendor Capacity $\ldots \ldots \ldots \ldots \ldots \ldots \ldots \ldots \ldots$

5 Predicted Buyer Payments Compared with Price Sensitivity $\ldots \ldots \ldots \ldots \ldots \ldots$

6 Payments vs. Vendor Fixed and Variable Costs $\ldots \ldots \ldots \ldots \ldots \ldots \ldots \ldots \ldots \ldots$ 


\section{ACKNOWLEDGMENTS}

This document is derived from work done for the TWRS Contractor Support Team, under the direction of Robert Broderson and Jerry Straalsund of Pacific Northwest National Laboratory (PNNL).

The authors wish to thank Gale Boyd of Argonne National Laboratory (ANL), Robert Drake of Los Alamos National Laboratory, and Mark Weimer of PNNL, as well as Drs. Broderson and Straalsund, for their insights and support in the preparation of this material. Design and publishing support was provided by ANL's Information and Publishing Division. 


\title{
PRICE COMPETITION IN PROCUREMENT
}

by

J.M. Keisler and W.A. Buehring

\begin{abstract}
When creating a private market to provide a public good, government agencies can influence the market's competitive characteristics. Markets have predictable, but often counterintuitive, behaviors. To succeed in applying available controls, and thereby reduce future costs, agencies must understand the behavior of the market. A model has been constructed to examine some issues in establishing competition for a structure in which there are economies of scale and government is obligated to purchase a fixed total quantity of a good. This model is used to demonstrate a way to estimate the cost savings from several alternative plans for a buyer exploring competitive procurement. The results are not and cannot be accurate for budgeting purposes; rather, they indicate the approximate magnitude of changes in cost that would be associated with changes in the market structure within which procurement occurs.
\end{abstract}

\section{INTRODUCTION}

\subsection{GOVERNMENT AGENCIES AND COMPETITIVE BIDDING}

As budgets decrease, government agencies are under increasing pressure to reduce costs without compromising their missions. An important mechanism for cost-cutting is procurement practices that facilitate competition among vendors, so that government agencies benefit from the efficiencies inherent in private enterprise. Often, the government is the only customer for certain products or services; that is, a natural market for such products does not exist. In such cases, the government must create a market structure by defining the rules by which firms must play.

The challenge is to define rules that create enough competition to be cost-effective without deterring entrants; give and take is necessary between government and potential vendors. A model has been designed to examine some tools that the government can use in establishing this market. This report provides general insights and specific process recommendations (e.g., questions to ask, 
factors to quantify) for decision makers. The goal is to transmit some lessons learned from previous modeling efforts for the benefit of future procurement managers.

In this report, it is assumed that the government (or another monopsonistic buyer) wishes to procure a fixed quantity of a good over a fixed time. The ability to establish and maintain a sufficient level of competition among vendors is one of the major uncertainties that affects the cost of services procurement, and one of the least understood. For example, it is unclear to policy makers whether one or two vendors, or even more, are needed to ensure price competition. Through economic theory and, in particular, industrial organization, methods have been developed to describe and predict the competitive environment for an industry.

The situation considered in this report is a fairly typical government procurement problem. The good being procured is not a commodity for which a competitive market price has been established. Rather, the government, as the primary customer, must agree on a price with its vendors. Economies of scale are assumed to be present, which means that (1) barriers to entry exist, and (2) the least-cost solution in the absence of transaction costs is to have a regulated monopoly, i.e., a single company providing the good for a standardized rate of profit. In addition, it is assumed that the government is obligated to purchase a predetermined quantity of the good. Thus, at the time of initial bids, a monopsony is in place so that competitive prices might be anticipated.

Once a vendor signs the contract, however, simple bilateral negotiation takes place between a monopsonist and a monopolist, with no clear equilibrium price. Because the government must purchase a fixed quantity, its prospects for obtaining a presigning equilibrium price are low; the vendor can be expected to raise the price, renegotiating on the basis of some unforeseen contingency, to a new "equilibrium." If significant transaction costs are involved in writing a contract precisely enough to preclude such contingencies, the opportunistic vendor can take advantage of the situation.

This report explores the circumstances under which the excess vendor profits caused by asymmetric power offset the greater cost-efficiency of a single-vendor solution. In other words, this report examines the optimal excess capacity to build in order to establish competition. The answer depends on several quantifiable characteristics (described later). The intent is that the insights and lessons learned from this model can be applied to similar future procurement transactions.

Accordingly, an economic model of the competitive bidding process was developed and explored. Numerous scenarios were defined in terms of the set of vendors, their fixed and variable cost structures, their capacities, and the allocation rule by which market share is determined on the basis of the prices bid. For each scenario, the model computes the Nash equilibrium (i.e., a set of prices bid by each vendor, so that no vendor can improve its position by raising or lowering its price). When the Nash equilibrium exists, a unique set of bids holds up if all firms try to maximize profit. Other models may suggest different equilibria based on different assumptions about vendor behavior (e.g., price leader/follower models). 
Realistic predictions for what will happen when the government attempts competitive procurement are hard to obtain. For this report, a number of stylized scenarios have been analyzed to explore specific questions (one issue per scenario). The findings are then summarized as general insights and specific estimates of cost savings under defined competitive conditions for sample scenarios. The primary finding is that the cost reduction attainable through wise management of the competitive environment can be of the same order as the total cost of the project.

It is difficult to quantify the competitive situation that would be best for a given agency. Simulation of the competitive environment makes it possible to explicitly compute the premium the government agency would pay over the vendor's actual costs. Simulation also takes into account how much power (i.e., ability to create a situation to one's liking) the situation gives to the government and various vendors.

These results are not "recommendation quality" because the input numbers are artificial data used solely for demonstration and discussion. The general conclusions drawn from the scenarios examined are true for any numbers used, but in the future, the precise dollar costs will change. The model is only as effective as the risk study data and the cost estimates included in it.

\subsection{LEVEL OF COMPETITION}

Understanding how to create and maintain competition (in the context assumed here) could allow agencies to lower costs. The benefits of different degrees of understanding are listed below:

- If prices were set below those determined through a competitive process, there would be a constant threat that prices would be raised under any pretext. In fact, prices would probably be raised once the agency's dollar limit was discovered.

- If prices were set above those of a competitive equilibrium, the government agency would pay less if it allowed competition to set prices.

- If a government agency understands what a sufficient level of competition is, it can establish and maintain adequate and consistent competition for the duration of a program.

- If competition adequately determines prices, an adverse change in a vendor's situation could lead to renegotiation of a price that would be competitive, while still fairly addressing changes in circumstances. Without sufficient competition, on the other hand, renegotiation is more a threat than a matter of fairness. 
- If an agency understood the effect of competition on its own costs, it would better understand whether vendor profits are reasonable - some vendor profitability, but not too much, is good for the government because it keeps multiple competitors in business. Bids that appear to provide insufficient profitability could be attempts to force out competitors. 


\section{THEORETICAL BACKGROUND}

This section describes the characteristics that, when present, make competitive procurement an attractive option for government agencies.

\subsection{CUTTING COSTS}

Experience with procurement shows that appropriate competition often cuts costs, but it does not explain how costs are lowered. "Procurement" refers to a situation in which a single purchaser (usually a government agency) buys a product or service for its own use; it is assumed in this report to require the development of dedicated facilities. Significant differences exist between government-agency-style procurement of management services and classic, military-style procurement of weapons.

Examined in this report are the development and provision on a long-term basis of an essentially continuous flow of product with significant fixed and variable costs. A number of technical solutions to the government's procurement problem are possible. With this type of economic structure, common in large-scale procurement scenarios, the government may benefit from establishing competition.

\subsection{FEASIBILITY AND BENEFITS}

In theory, competition is sometimes, but not always, feasible and beneficial in procurement. Basically, the procurement process consists of two stages: bidding and post-contract. The potential for competition in the bidding stage is great, whereas vendors often attempt to raise prices during the latter stage. Once work begins, the chances of keeping a tight competitive lid on prices can decrease because the government agency may be unable to switch vendors in the middle of a project. Second sourcing can help resolve this problem.

Deciding whether competition is worthwhile and should be encouraged depends on several factors: the constraints, goals, and specific details of the situation; the feasibility of creating competition; the costs of maintaining competition (and excess vendors and capacity); and the benefit in terms of reduced prices (or at least prices that are not raised) from competition. Tables $1 \mathrm{a}, 1 \mathrm{~b}$, and 1c provide an incomplete list of such factors. It is a matter of judgment where any specific situation lies on the spectrum for each factor and whether the net effect of these factors strengthens competition. 
TABLE 1a Factors Relating to Benefits of Market Solution

\begin{tabular}{lcc}
\hline \multicolumn{1}{c}{ Factor } & $\begin{array}{c}\text { Benefit of Multiple } \\
\text { Sourcing Is } \\
\text { High If Factor Is }\end{array}$ & $\begin{array}{c}\text { Benefit of Single } \\
\text { Contractor Is } \\
\text { High If Factor Is }\end{array}$ \\
\hline Capacity & High & Low \\
Economies of scale & Low & High \\
Potential price sensitivity & High & Low \\
Length of commitment & Short & Long \\
Barriers to late entry/reentry & High & Low \\
Learning potential & Significant & Insignificant \\
Ability of buyer to walk away & Unclear & Unclear \\
from a particular seller & Low & High \\
Opportunity cost & No & Yes \\
Buyer knows costs & & \\
\hline
\end{tabular}

TABLE 1b Factors Relating to Risk of Collusion

\begin{tabular}{lcc}
\hline \multicolumn{1}{c}{ Factor } & $\begin{array}{c}\text { Collusion } \\
\text { Is Likely If } \\
\text { Factor Is }\end{array}$ & $\begin{array}{c}\text { Collusion } \\
\text { Is Unlikely } \\
\text { If Factor Is }\end{array}$ \\
\hline $\begin{array}{l}\text { Complexity of technology } \\
\text { Complexity of price format }\end{array}$ & Low & High \\
$\begin{array}{l}\text { Number of big players } \\
\text { Ease of communication } \\
\text { between players }\end{array}$ & Few & High \\
Frequency of purchase & Easy & Hard \\
\hline
\end{tabular}

\subsection{DATA ON THE BENEFITS OF COMPETITION}

Limited data are available on the benefits of competition in procurement. Data may be limited because of the long lag time between the start of a procurement "test" and the incorporation of its results into data sets. Because empirical information is limited (billions of dollars are needed to run a reasonable test), many researchers use the same data. Although it is worthwhile to consider the data, it is also necessary to assess how well those data apply to any specific procurement situation. The lack of data makes it necessary to rely, to some extent, on theoretical models and to evaluate the reasonableness of their implications for procurement. Current literature is reviewed in Table 2. 
TABLE 1c Factors Favoring Private

Contractor vs. Government Control

\begin{tabular}{|c|c|c|}
\hline Factor & $\begin{array}{c}\text { Private } \\
\text { Contractor } \\
\text { Favored If } \\
\text { Factor Is }\end{array}$ & $\begin{array}{c}\text { Government } \\
\text { Control } \\
\text { Favored If } \\
\text { Factor Is }\end{array}$ \\
\hline $\begin{array}{l}\text { Severity of impact } \\
\text { of failure }\end{array}$ & Low & High \\
\hline Externalities & Low & High \\
\hline Collective interests & Low & High \\
\hline Distributional goals & Low & High \\
\hline $\begin{array}{l}\text { Does process affect } \\
\text { preferences? }\end{array}$ & No & Yes \\
\hline $\begin{array}{l}\text { Equity among } \\
\text { bidders }\end{array}$ & Yes & No \\
\hline
\end{tabular}

\subsection{SUMMARY OF THEORETICAL AND EMPIRICAL LITERATURE}

Future situations will have unique characteristics, so it is not possible to rely solely on experience. Decisions about the level of competition must be made under uncertain conditions. In general, however, the data seem to support dual sourcing and bids by private contractors.

Theoretical arguments (not detailed here) also tend to support competition for cases that do not fall clearly into either pure competition or pure government control. The existence of such techniques as lowballing (and the expectation of barriers to entry after contracting) favors ongoing competition after initial contracts are awarded. The presence of economies of scale and the potential for implicit collusion make it less attractive to try to establish ongoing competition; however, laws are in place to prevent explicit collusion.

A solution to the problem involves variations on basic competitive themes (e.g., multiple sourcing, competitive bidding). Such a solution incorporates many of the benefits of competition and avoids the factors that make this situation less amenable to pure competition. 
TABLE 2 Empirical Data on the Benefits of Competitive Procurement

\begin{tabular}{|c|c|c|}
\hline Source & Main Point/Subject & Data \\
\hline $\begin{array}{l}\text { Uttley } \\
\text { and } \\
\text { Harper } \\
\text { (1993) }\end{array}$ & $\begin{array}{l}\text { Privatization of local services. } \\
\text { Investigation of the effect of introducing } \\
\text { a competitor to government. }\end{array}$ & $\begin{array}{l}\text { With competition, the private provider outbid government } \\
80 \% \text { of the time, with an average savings of } 20 \% \text {. The } \\
\text { primary source of savings was technology, with secondary } \\
\text { savings because people work more hours for less pay. }\end{array}$ \\
\hline $\begin{array}{l}\text { Hilke } \\
\text { (1992) }\end{array}$ & $\begin{array}{l}\text { Analysis of Department of Defense } \\
\text { studies concludes that their value is } \\
\text { limited. Savings come from allocative } \\
\text { efficiency (e.g., prices determine what } \\
\text { gets made) and production efficiency } \\
\text { (e.g., better management, better } \\
\text { technology). }\end{array}$ & $\begin{array}{l}\text { Private providers won } 65 \% \text { of competitions, and the } \\
\text { government won } 35 \% \text {, with average savings of } 35 \% \text { in } \\
\text { both cases. Increasing competition is difficult because } \\
\text { dollar benefits are delayed. Postcontractual opportunism } \\
\text { occurs to a modest extent. Cost savings are estimated at } \\
\$ 10,000 / \text { employee. }\end{array}$ \\
\hline $\begin{array}{l}\text { Pilling } \\
\text { (1989) }\end{array}$ & $\begin{array}{l}\text { Existing data are of poor quality. } \\
\text { Analyzes military procurement for items } \\
\text { costing less than } \$ 10,000 \text { each. }\end{array}$ & $\begin{array}{l}\text { Second sourcing prevents prices from being raised but } \\
\text { does little to reduce prices. One in } 17 \text { initial producers } \\
\text { wins in later competition, which implies that second } \\
\text { sourcing does not force much learning for the primary } \\
\text { source. Rather, it suggests that the runner-up price in the } \\
\text { first period should be a contract to develop design for the } \\
\text { second period. }\end{array}$ \\
\hline $\begin{array}{l}\text { Carrick } \\
\text { (1988) }\end{array}$ & $\begin{array}{l}\text { The Navy Commercial Activity program } \\
\text { is analyzed, with a focus on how often } \\
\text { government bids beat private contractors } \\
\text { (generally on small-scale items). }\end{array}$ & $\begin{array}{l}\text { Government does better than chance would predict; on } \\
\text { average, it is no less or more efficient than private } \\
\text { contractors. Efficiency is realized, however, only when } \\
\text { competition is opened. }\end{array}$ \\
\hline $\begin{array}{l}\text { Anton } \\
\text { and Yao } \\
(1990)\end{array}$ & $\begin{array}{l}\text { Empirical models and data are flawed. } \\
\text { Offers methodology that compares } \\
\text { predicted cost curve without competition } \\
\text { to actual cost curve. }\end{array}$ & $\begin{array}{l}\text { The median savings from competition was } 37 \% \text { (ranging } \\
\text { from } 0 \text { to } 60 \% \text { ). "Winner-take-all" awards do better than } \\
\text { split awards (can be implemented after a learning period). } \\
\text { The number of bidders is not significant in predicting } \\
\text { savings. The initial savings were } 24-40 \% \text {, which } \\
\text { represents a small improvement in the learning curve. } \\
\text { Savings result from reduced margins and costs. Suggests } \\
\text { competition when capacity utilization is }\end{array}$ \\
\hline $\begin{array}{l}\text { Morgan } \\
(1992)\end{array}$ & $\begin{array}{l}\text { Competition is necessary for savings in } \\
\text { privatization. }\end{array}$ & $\begin{array}{l}\text { Negative examples from Oklahoma Sewage are given, but } \\
\text { without statistics. }\end{array}$ \\
\hline $\begin{array}{l}\text { Poole } \\
(1988)\end{array}$ & $\begin{array}{l}\text { Local garbage pickup, municipal } \\
\text { building maintenance, etc. Analyzes } \\
\text { National Science Foundation study from } \\
\text { 1970s. }\end{array}$ & $\begin{array}{l}\text { Providing services in-house costs } 37-96 \% \text { more than } \\
\text { providing services from an outside source. }\end{array}$ \\
\hline $\begin{array}{l}\text { Pilling } \\
\text { (1989) }\end{array}$ & $\begin{array}{l}\text { The study examines the effect of } \\
\text { privatizing and competition in military } \\
\text { procurement. }\end{array}$ & $\begin{array}{l}\text { Cost index for competitive vs. noncompetitive awards. } \\
\text { Results show system performance: } 0.98 \text { vs. } 1.07 \text {; program } \\
\text { schedule: } 1.06 \text { vs. } 1.17 \text {; program cost: } 1.16 \text { vs. } 1.53 \text {. Note } \\
\text { that four of six winning contractors in a Naval study won } \\
\text { subsequent claims against government for inadequate data. } \\
\text { The other two also had expensive problems, such as } \\
\text { lowballing (need option to re-let) and accountability (need } \\
\text { performance bonds). }\end{array}$ \\
\hline
\end{tabular}




\section{EXAMPLES}

In this section, two examples are used to demonstrate a model developed to assist in understanding the effect of price competition in procurement. Section 4 shows results from a number of possible situations.

\subsection{BASE CASE}

The first example — the base case - operates under the following assumptions (numbers given are for illustrative purposes):

- The government agency requires 100 units of a product.

- Vendors set their price to maximize their profit.

- The government agency has two vendors with identical fixed and variable costs. (This strong assumption can later be relaxed.)

- Each vendor builds a plant that can fulfill $60 \%$ of the government's needs.

- The fixed cost to each vendor for building a plant is $\$ 1$ million.

- The vendor's per-unit variable cost of production is $\$ 71,500$. The base case assumes that variable costs per unit are constant. A more complex assumption could have been added (i.e., that operating costs consist of both a variable and a fixed component or that production costs behave in some other nonlinear way).

- Each vendor proposes to charge a fixed price per unit.

- Each vendor's costs are known to all vendors. This assumption keeps the model simple. Vendors use their best estimates about each others' and their own costs and bid to maximize their expected profit.

- Vendors cannot drop out; that is, they must accept any amount of production work they are awarded by the buyer up to their capacity. Although this assumption is not reasonable in most cases, it is included because it significantly simplifies the construction of the competition model. A more complex model could be developed in which this assumption does not hold. 
For the present purposes, when this assumption is critical, it is not used in drawing conclusions.

- The buyer allocates shares of the total production volume $S$ to the vendors on the basis of their proposed price $P$. Specifically, the base case assumes that each vendor receives a share $S_{i}$ based on its bid price $P_{i}$, the bid of the other vendor, and a price sensitivity parameter $g$, according to the logit function:

$$
S_{i}=P_{i}^{-g} /\left(P_{1}^{-g}+P_{2}^{-g}\right)
$$

More generally, $S_{i}=\left(P_{i}\right)^{-g} / \Sigma_{j}\left(P_{j}\right)^{-g}$. For example, if two vendors offer prices of $\$ 85,800$ and $\$ 114,450$ /unit (numbers fabricated), the first vendor's share for $g=2$ would be:

$$
85,800^{-2} /\left(85,800^{-2}+114,450^{-2}\right)=64 \%
$$

The logit function is used to describe the behavior of markets, such as energy markets (Baughman et al. [1974]), where price is an important, but not the only, determinant of share. It is often used to estimate the probability that a single consumer will choose one product in cases having multiple attributes of unknown value. By using actual aggregate government (or consumer) purchase data, the logit function is applied in the reverse direction to estimate the trade-off values that government agencies place on different product attributes (McFadden [1975, 1976]). Particular services have multiple attributes, and some are specified (i.e., cost per unit in some dimensions). For each microlevel decision (e.g., government offers a small fraction of the total 100 units in each contract), it is reasonable to predict the probability that one vendor will be preferred over another by using the logit function, and therefore the aggregate share achieved by each vendor would be that given by equation 1. This assumption about how the buyer allocates market share is for convenience. The actual rule may or may not be under the buyer's control and depends on much more detailed price and value factors than could be specified in the future.

In this case, the parameter $g$ (or gamma) represents the sensitivity of a vendor's share (allocated by the buyer) to the price it proposes to charge. The higher $g$ is, the more important price is in determining share. Specifically, when $n$ identical vendors start with the same price, the percent increase in a 
vendor's volume for a $1 \%$ drop in price is $g \times(n-1) / n$. For example, consider two vendors who initially bid $\$ 286,000 /$ unit for a total of 100 units, and $g=3$. If one vendor were to reduce its price by $1 \%$ to $\$ 283,140 /$ unit, the buyer would increase the work awarded to that vendor by $1.5 \%$, from 50 to 50.75 units.

The desire to maintain competition, as well as differential capabilities of vendors and friction in shifting of production between plants, may make pure price competition unlikely, so $g$ is set at a moderate level of price sensitivity (2.5) in the base case. In empirical work on energy choice, cross price elasticities range from 2 to 3 . The range of what is reasonable could vary significantly on the basis of what is done to improve the government's flexibility in switching allocations of share based on price.

A policy in which share does not depend on bid price would correspond to $g=0$. A policy in which the low bidder always produces and sells to the government as much as it can buy would correspond to an infinite value of $g$.

The actual sensitivity of share to price is determined by such factors as uncertainty, switching costs, diseconomies of scale, political pressures, and the need to ensure continuing competition over time. The combination of these factors determines, for example, whether government should establish a winner-take-all market because of its production economies of scale.

\subsection{OPERATING THE COMPETITION MODEL IN THE BASE CASE}

The competition model determines the prices that vendors charge the government in a oneperiod model (i.e., prices and shares are set once and assumed to stay constant for the duration of the program). To determine costs from competition, the model starts vendors at prices equal to their marginal costs. For each set of prices, the model computes a vendor's profits. The profit $\operatorname{Pr}$ for each vendor is defined as:

$$
\operatorname{Pr}=(P-V) \times Q-F
$$

where:

$$
\begin{aligned}
& P \quad=\text { price charged to the buyer per unit; } \\
& V \quad=\text { variable cost per unit; }
\end{aligned}
$$




$$
\begin{aligned}
& Q \quad=\text { quantity produced (output); and } \\
& F \quad=\text { fixed cost for building a plant. }
\end{aligned}
$$

The model then simulates a cycle in which the first vendor raises prices to the point of maximum profit, that is, where additional price increases would reduce profit by more than a threshold level because the effect of decreasing market share more than offsets the effect of increasing revenue per unit. The second vendor also adjusts prices to the profit maximizing level, assuming the first vendor's prices remain unchanged. This cycle continues until neither vendor acting on price alone can improve its profit.

This set of prices is called an "equilibrium." In this case, an equilibrium unit price calculated by the model is $\$ 356,700$ for both vendors, although if the vendors had different cost structures, they would probably charge different prices in equilibrium. Each vendor receives $50 \%$ of the total production order. Again, if the vendors had different cost structures, they would probably receive different shares.

\subsection{EQUILIBRIUM PRICES AND THEIR RELEVANCE}

The market equilibrium price expresses the level of competition to the world, and this concept is critical in understanding the benefits of competition. A market is in equilibrium when the set of prices and corresponding volumes is such that no single firm can improve its expected profit by either raising or lowering its price. The competition model computes the market equilibrium, prices, and market share by simulation. Mathematically, equilibrium occurs when the derivative of profit with respect to price is zero for each firm:

$$
\begin{aligned}
d \operatorname{Pr}_{i} / d P_{i} & =\partial P r_{i} / \partial P_{i}+\left(\partial P r_{i} / \partial Q_{i}\right) \quad\left(\partial Q i / \partial P_{i}\right) \\
& =Q_{i}+\left(P_{i}-V_{i}\right)\left(\partial Q_{i} / \partial P_{i}\right)=0
\end{aligned}
$$

When equation 1 is used to compute share and the price is expressed in dollars per unit share, the equilibrium can be computed analytically, through a bulky equation, by setting the total derivative of profit with respect to price to zero for each vendor. Equilibrium is important for the following reasons:

- Equilibrium arises when vendors act in their own self-interest. For this reason, equilibria are self-regulating in contrast to mandated price schemes.

- For economic analysis in a private business-driven system, equilibrium analysis is the only way to estimate (or influence) prices. In general, controls 
on prices that conflict with equilibrium prices are artificially imposed and impinge on free enterprise, which tends to reduce efficiency.

- Because the conditions for what constitutes equilibrium are precisely defined, equilibria (if they exist) can be estimated with precision if data are complete. This fact allows a quantitative simulation of the effect of changes to the plan, rather than mere speculation about whether those changes would lower procurement costs.

Returning to the base case, in an equilibrium, the vendors' total revenues are about $\$ 17,835,000$ each $(50 \times \$ 356,700)$, and their total costs are $\$ 4,575,000$ each $([50 \times \$ 71,500]+$ $\$ 1$ million). The difference between revenues and costs is profit, which, in this case, is $\$ 13,260,000$ per vendor.

To test whether the outcome predicted for the base case is an equilibrium, consider the following experiment: if the first vendor raised its price to $\$ 372,000 /$ unit to try to increase profit, the buyer would purchase fewer units (i.e., 47.4 units), and the vendor's profit would drop to $\$ 13,250,000$ in spite of its increased price. Conversely, if the first vendor lowered its price to $\$ 343,400 /$ unit to try to take more of the second vendor's share, its share would rise only to 52.4 units, which is not enough to offset its lost revenues, as the new profit would be $\$ 13,255,000$. The same applies for the second vendor.

Interestingly, these equilibrium prices are far above vendor costs. Although the total cost incurred by vendors ([fixed costs + variable costs] $\times$ units) is only $\$ 9,150,000$, the buyer pays $\$ 35,670,000$ for the product. The vendors' profit is $\$ 26,520,000$. Even an inefficient cost-plus contractor would probably cost government less. The problem is that this case does not have sufficient real competition to control prices.

A simple algebraic formula is not available to determine an equilibrium in all cases. However, economics textbooks give the general characteristics of an equilibrium when the relationship between price and share is well behaved (e.g., share decreases smoothly as price increases, going asymptotically to zero as price increases and to one as price decreases, with no points of inflection in between). Specifically, the first-order partial derivatives of profit with respect to all controllable variables are zero for all firms, and the second-order partial derivatives (the Hessian) are all negative. 


\subsection{CAPPING PRICES}

The government agency could set a cap below the prices (e.g., $\$ 228,900 /$ unit) referred to in Section 3.3, which would result in a total cost to that agency of $\$ 22,890,000$. The vendors would still profit enough to accept the proposal. For efficiency, it could select a single supplier at such a price. Common economic advice for dealing with monopolies is to impose an up-front charge in return for granting a monopoly, where the charge is large enough to make up for the later excess profits expected to accrue to the monopolist.

The problem, however, is that government agencies often lack flexibility in the quantity needed. If the agency sets a price cap and the vendors raise prices to that cap, there is no real competition. If competition were sufficiently intense, the market would self-regulate, and the competitively determined prices would be below the agency's price cap.

\subsection{BASE CASE PLUS INTENSE COMPETITION}

In this second case, all factors are identical to those in the base case, except that a third vendor, with a cost structure and capacity similar to the first two (fixed costs of $\$ 1$ million, variable costs of $\$ 71,500 /$ unit, $60 \%$ capacity) is added. The simulated bidding process now leads to an equilibrium price of $\$ 178,100$ for the three vendors. Each vendor receives one-third of the total volume to be produced and sustains lower (though still substantial) profits of $\$ 2,575,000$. The total costs incurred by vendors are somewhat higher - $\$ 10,157,400$ - because a third plant has been built. Total payments by the government agency, however, are reduced by $50 \%$ (i.e., $\$ 17,800,000$ ).

In this case, the threat of being undercut by the other vendors keeps each vendor from raising its prices. Therefore, adding a third vendor saves the government about $\$ 18$ million. Also, the presence of both additional capacity and vendors increases the buyer's power (e.g., its ability to shop around) compared with that of the vendor.

These two cases illustrate an important lesson. Rather than simply focusing on understanding vendor costs, which would be appropriate for cost-plus-type contracting, it is also important for the government agency to recognize the competitive environment in which contracts are signed and prices are set. Regardless of what the buyer wants to pay, the vendors will charge what the buyer will bear unless the vendors keep each other in check. 


\section{EXPLORATORY EXAMPLES FOR SPECIFIC FACTORS}

This section contains variations on the base case example to approximate systematically the impact of other factors on government agency costs. For each factor (number of vendors, total capacity, price sensitivity, cost structure), an equilibrium resulting from each of a range of possible values is computed, and the results are tabulated. The following results of scenarios are summarized: how the situation varies from the base case; what are the new government costs and other outputs; and what lessons should be drawn from the result.

\subsection{GOVERNMENT PAYMENTS AND THE NUMBER OF VENDORS}

Starting with the base case, the number of vendors was varied from one to five; all other factors remained constant. It was determined that government costs would drop by $60 \%$, particularly when four vendors were bidding. Using five vendors drives profits to near zero. More than five vendors makes the market unprofitable and therefore unsustainable (Table 3). Therefore, when share is only moderately sensitive to price ( $g=2.5$ ), the difference between two and three competing vendors is critical for government agencies.

\subsection{EFFECT OF VENDOR CAPACITIES ON GOVERNMENT PAYMENTS}

Vendor capacity is only a factor under certain conditions, but it has a surprisingly large impact on the buyer's power relative to the vendors' power. Therefore, it also greatly affects price.

The base case is modified, setting $g=3$, to intensify the effect. The capacities of the two vendors vary from 40 to $110 \%$. The effect of a redundant vendor is not apparent in this case, but it

TABLE 3 Predicted Government Payments Compared with the Number of Vendors

\begin{tabular}{cccc}
\hline $\begin{array}{c}\text { No. of } \\
\text { Vendors }\end{array}$ & $\begin{array}{c}\text { Government } \\
\text { Payments } \\
(\$)\end{array}$ & $\begin{array}{c}\text { Total Vendor } \\
\text { Cost } \\
(\$)\end{array}$ & $\begin{array}{c}\text { Average } \\
\text { Vendor Profit } \\
(\$)\end{array}$ \\
\hline & & & \\
1 & Upper limit & $8,154,000$ & Upper limit \\
2 & $35,600,000$ & $9,156,000$ & $13,233,200$ \\
3 & $17,800,000$ & $10,157,400$ & $2,575,100$ \\
4 & $15,000,000$ & $11,158,800$ & $1,073,000$ \\
5 & $14,300,000$ & $12,160,200$ & 429,200 \\
\hline
\end{tabular}


is evident in cases with three vendors. The cost to the buyer drops slightly when there is a redundant vendor but does not drop when there are two vendors, at least with the base case level of price sensitivity and symmetric vendors. However, when one vendor is even slightly capacity constrained, the buyer's cost increases by $20 \%$. When both are capacity constrained, there is no equilibrium. Table 4 shows the relation of predicted payments to vendor capacity.

A vendor is "capacity constrained" when the share it would receive in equilibrium based on its costs alone is greater than its capacity. In this case, the vendor cannot produce the volume demanded at the prices that would arise in an unconstrained equilibrium. Therefore, the vendor can raise prices above the unconstrained equilibrium price without decreasing its actual production volume.

In general, the capacity-constrained vendor contributes almost nothing to the competitive environment. For example:

- If a bidder cannot be completely excluded because the total capacity of other bidders is less than $100 \%$, the high-cost vendor is guaranteed a share.

- The vendor with low costs may charge the highest price if it is capacity constrained; alternatively, the vendor with highest fixed costs may have the largest per-unit profit margin if it is capacity constrained.

Although the trend sometimes occurs because of the way in which the model estimates vendor cost structures as a function of capacity (it assumes significant decreases in variable costs for larger capacity plants), the major impact on buyer costs is from capacity constraints.

The primary lesson in this case is that an effective competitive environment exists only when vendors have excess capacity; under these conditions, vendors would like a greater share (without reducing price), while government agencies could afford to offer a lower share, which

TABLE 4 Relation of Predicted Payments to Vendor Capacity

\begin{tabular}{cccc}
\hline $\begin{array}{c}\text { Vendor } \\
\text { Capacities } \\
(\%)\end{array}$ & $\begin{array}{c}\text { Government } \\
\text { Payments } \\
(\$)\end{array}$ & $\begin{array}{c}\text { Total Vendor } \\
\text { Cost } \\
(\$)\end{array}$ & $\begin{array}{c}\text { Average } \\
\text { Vendor Profit } \\
(\$)\end{array}$ \\
\hline 48,48 & Upper limit & $9,012,900$ & Upper limit \\
40,80 & $42,920,000$ & $9,155,900$ & $16,811,300$ \\
60,60 & $21,460,000$ & $9,155,900$ & $6,151,600$ \\
80,80 & $20,030,000$ & $9,012,900$ & $5,436,300$ \\
\hline
\end{tabular}


favors the agencies' power in determining price. When capacity is constrained, the agency would like to purchase more products than the vendor can provide, which means the vendor has more power.

In an extreme case (not discussed in this report), at least one vendor's capacity would be entirely redundant (i.e., the capacity of the other vendors would total more than $100 \%$ of the buyer's needs). When vendors have markedly different costs, this situation is particularly advantageous for government agencies because it might be desirable to eliminate a high-cost player. The base case does not indicate any benefit from maintaining a large excess capacity.

\subsection{EFFECT OF BUYER'S SENSITIVITY AND PRICE ON PAYMENTS}

The price sensitivity parameter $g$ was varied from the base case from two (low but nonzero price sensitivity) to complete (infinite) price sensitivity. This variable becomes very important. As sensitivity varies, the buyer's costs range from the maximum possible (the buyer's total budget) to the minimum possible (the vendor's marginal costs). Most of this change occurs within a fairly small range of price sensitivity (Table 5).

When relatively few vendors compete, it is important to impose sufficient competitive pressure in the way share is allocated as a function of price:

- Below a certain level of price sensitivity (e.g., $g=2$ ), no equilibrium is present. Prices are unstable and spiral out of control. Each time the two vendors offer the same price, they benefit by raising prices because the penalty in terms of lost shares is minimal.

- An important implication of this finding is that a simple 60/40-type rule, in which the low bidder receives a $60 \%$ share and the high bidder receives a $40 \%$ share, in some cases translates to a price sensitivity that is completely ineffective in inducing competition.

- Although it is not illustrated in Table 5, the more vendors, the less price sensitivity is required for an equilibrium to exist; e.g., when three vendors are bidding, $g=2$ is sufficient to reduce payments to the same level as for $g=3$ in the two-vendor case. 
TABLE 5 Predicted Buyer Payments Compared with Price Sensitivity

\begin{tabular}{lccc}
\hline Buyer Price & $\begin{array}{c}\text { Buyer } \\
\text { Payments } \\
\text { Sensitivity }\end{array}$ & $\begin{array}{c}\text { Total } \\
\text { Vendor Cost } \\
(\$)\end{array}$ & $\begin{array}{c}\text { Average } \\
\text { Vendor Profit } \\
(\$)\end{array}$ \\
\hline & & & \\
Low $(g \leq 2)$ & Upper limit & $9,155,900$ & Upper limit \\
Mild $(2.5)$ & $35,765,400$ & $9,155,900$ & $13,233,200$ \\
Moderate (3) & $21,459,200$ & $9,155,900$ & $6,151,600$ \\
High $(5)$ & $11,874,100$ & $9,155,900$ & $1,359,100$ \\
Complete & $7,153,100$ & $9,155,900$ & $-1,000,000$ \\
\hline
\end{tabular}

\subsection{EFFECT OF PROPORTION OF FIXED-TO-VARIABLE COSTS ON PRICING}

Vendor cost structures (assuming lower variable costs are associated with higher fixed costs) range from all fixed to all variable. Assumptions about the cost-capacity relationship are modified to ensure that each vendor incurs approximately the same total cost in each case. Starting with the base case, and not changing any other assumptions, vendor capacity is set at $80 \%$ each rather than $60 \%$, so that fixed costs are higher and variable costs are lower.

In the first variation, the price drops from $\$ 27,181 /$ unit to $\$ 21,459 /$ unit, so the buyer's costs drop $\$ 5.7$ million. 'Although the vendor's total costs are nearly unchanged, the profit per vendor drops $\$ 2.8$ million.

Table 6 illustrates an important point: relatively low variable costs and high fixed costs lead to increased price competition in an ongoing market. One interpretation of this point is that any technology development that reduces variable cost for any vendor is good for the buyer, even vendor proprietary technology.

In this model, fixed costs do not affect bids unless vendors are forced out (and have the option of exiting the market). In reality, fixed costs affect bids whenever a vendor is assumed to lose money - vendors' prices include a sufficient cushion over the marginal cost to cover their fixed costs; otherwise, they do not want the contract.

The effect of asymmetric vendor costs can be explained as follows. When one vendor has lower costs, these costs are partially passed on to the buyer as savings; however, the benefit to the buyer is greatest when at least two vendors have low costs because price is largely driven by the second lowest cost producer. Reductions in cost to any vendor should be good for the buyer, but it is better if these reductions are more evenly spread among vendors. 
TABLE 6 Payments vs. Vendor Fixed and Variable Costs $(g=2.5)$

\begin{tabular}{|c|c|c|c|}
\hline $\begin{array}{l}\text { Fixed and Variable } \\
\text { Costs per Unit } \\
(\$)\end{array}$ & $\begin{array}{c}\text { Buyer } \\
\text { Payments } \\
(\$)\end{array}$ & $\begin{array}{c}\text { Total } \\
\text { Vendor Cost } \\
(\$)\end{array}$ & $\begin{array}{c}\text { Average } \\
\text { Vendor Profit } \\
(\$)\end{array}$ \\
\hline $\begin{array}{l}\text { Fixed: } 0 \\
\text { Variable: } 90,129\end{array}$ & $27,181,700$ & $9,155,900$ & $9,012,900$ \\
\hline $\begin{array}{l}\text { Fixed: } 1,000,000 \\
\text { Variable: } 71,531\end{array}$ & $21,459,200$ & $9,012,900$ & $6,223,200$ \\
\hline $\begin{array}{l}\text { Fixed: } 1,251,800 \\
\text { Variable: } 66,524\end{array}$ & $20,028,600$ & $9,012,900$ & $5,507,900$ \\
\hline $\begin{array}{l}\text { Fixed: } 1,430,600 \\
\text { Variable: } 61,516\end{array}$ & $18,598,000$ & $9,155,900$ & $4,721,000$ \\
\hline $\begin{array}{l}\text { Fixed: } 9,155,900 \\
\text { Variable: } 0\end{array}$ & 0 & $9,155,900$ & $-4,578,000$ \\
\hline
\end{tabular}




\section{RESULTS}

\subsection{LIMITATIONS ON THE INTERPRETATION OF RESULTS}

The exact relationship between payments and competitive conditions, in practice, depends on many considerations. Costs cannot be known with certainty, and the cost structures of vendors are more complex than the one in this model. In addition, substitute products may be available for both buyer and seller.

This model describes ongoing competition in a market rather than initial bidding for a market. If variable costs are held constant, fixed costs are actually irrelevant to the results, except for situations in which at least one bidder operates at a loss. These situations are unstable. (A vendor would continue to operate at a loss, however, when the government agrees to "lease back" a production facility, so that some rent is paid each period as long as it operates.) In bidding situations, vendors will not bid at prices for which they anticipate a loss.

The cost structures assumed in the model may be conservative. Over time, vendors have incentives to cut costs to gain share or profit margin. The process assumed in the model is also not entirely realistic because:

- When the payments are exorbitant, the buyer would likely impose a price cap, which vendors would accept so long as they could still make a profit.

- The "spiraling" of prices that occurs in the model does not occur in real time but is meant to represent what happens in the mind of a strategically thinking bidder.

However, what is true in simple cases (in terms of general factors that affect prices and the order of magnitude of their effects) also tends to be true (within reasonable bounds) in complex cases: savings are comparable, even if they are harder to identify because of all the other factors contributing to prices. 


\subsection{SUMMARY OF KEY LESSONS}

The following list represents the key lessons learned about how price competition affects government agencies:

- Increased competition tends to accompany increased total costs to vendors because of the fixed costs of additional production facilities. A happy medium is present where vendor costs - and vendor margins - are reasonably low.

- The different factors that can influence the level of competition have diminishing marginal effects on price, individually and collectively.

- For the case examined here, increasing the number of vendors has a significant effect up to four vendors. It is even possible that costs could be lowered by subsidizing extra vendors.

- Increasing price sensitivity has a strong effect, until moderately high levels are reached; with two vendors, the cutoff occurs approximately when a $1 \%$ increase in price leads to a $3.5 \%$ decrease in the amount a vendor sells. The cutoff would be lower if more vendors participated or if other factors increased competition.

- The ratio of fixed-to-variable costs is significant, but not as much so as the number of vendors and the buyer's price sensitivity. These depend, of course, on the ranges of possible values for each factor.

- Capacity must be high enough to support competition; i.e., some slack must exist, but more slack is not better after a point. Excess capacity is necessary, but not sufficient, for competition. 


\section{RECOMMENDATIONS}

To save money in the long term, the government agency as a buyer must make farsighted decisions regarding competition at the time it commits to establishing a private market to meet its demand. Suggested actions for government buyers facing a situation similar to that in this report include the following:

- Government buyers should ensure that vendors have some excess capacity (it does not take much excess to allow competition). Depending on the cost, the buyers should consider contracting for capacity where a redundant plant exists.

- If a fixed quantity of product is needed over a fixed period, an important relationship occurs between the schedule for production and the maintenance of competition. Hastening the schedule reduces the overall capacity as a percentage of the buyer's annual needs, which could eliminate competitive pressures. On the other hand, if capacity is expensive (i.e., it would be impossible to build excess capacity and remain within budget), the schedule could be relaxed, which would increase a plant's capacity as a percentage of the buyer's annual needs. Technology improvements that cut costs could also increase vendor capacities, which would give the buyer a competitive balance.

- Under competitive pressures similar to those in the model, government buyers should attempt to have four vendors (having fewer than four vendors results in conditions that are worse [three vendors] to catastrophic [one vendor]). If few vendors are available, the government should be extremely vigilant in enforcing a high sensitivity of vendor share to bid price. It may be worthwhile for the buyer to subsidize the entry of an extra vendor (possibly from a favored class, e.g., domestic vendors) to maintain competition. The margin for error in the number of vendors is small.

- The buyer should prefer products with relatively low variable costs, even if this preference leads to higher fixed costs (although this advice must be balanced by the cost in terms of financing and flexibility compared with lower up-front costs). The buyer may be able to lower variable costs for vendors by developing new technology for distribution to all vendors (e.g., developments at national laboratories). This method is most effective when it leads to more evenly distributed vendor costs, rather than when it helps one vendor achieve significantly lower costs. 
- Government buyers should develop systems that increase their ability to be price-sensitive (e.g., make it easy to compare bids, avoid getting locked into a price or a particular vendor's technology or location). In particular, rules in which the low bidder gets $60 \%$ of production and the high bidder gets $40 \%$ do not provide sufficient price sensitivity to ensure ongoing competition.

- Buyers should be realistic about what can and what cannot be controlled. For example, it is desirable to keep vendor costs low, but it is more important to keep buyer costs low. It is desirable to keep vendor margins reasonable, but buyers should not be concerned if vendors make a reasonable profit; it may be necessary to keep competition alive. Also, it may be impossible to simultaneously minimize vendor profit and buyer cost. The only reason for a buyer to try to manage vendor profit is to minimize buyer cost. This idea implies that micromanaging vendor costs, as they relate to bids, could be selfdefeating.

- Buyers should be aware of ways in which vendors might try to damage the competitive environment. For example, beware of bids that seem so low they would force another vendor out of business or of attempts to limit capacity. (On the other hand, if the threat of entry is maintained, such bids may be fortuitous for the buyer.) Buyers who anticipate such tactics may be able to preclude them through contract terms.

- Buyers should identify ways in which vendors may worry about the competitive environment being turned excessively against them and ensure that this action will not happen, especially if it is a prohibitive concern. Otherwise, attractive potential vendors will not want to bid.

Procurement of government services occurs in an artificial market, even if the market is competitive. Government buyers who use competitive procurement processes can save large sums of money or incur very high costs, depending on their actions at the time the rules of competition and the structure of the artificial market are established. This report examines issues that affect the ability of buyers to achieve their desired outcomes. The modeling approach can be used to estimate the magnitude of the impact of different factors and to predict the costs associated with a contemplated competitive procurement process. 


\section{BIBLIOGRAPHY}

Anton, J.J., and D. Yao, 1990, "Measuring the Effectiveness of Competition in Defense Procurement: A Survey of the Empirical Literature," Journal of Policy Analysis and Management 9(1).

Baughman, M.L., and P. Joskow, 1974, Interfuel Substitution in the Consumption of Energy in the United States, MIT-EL74-002, Massachusetts Institute of Technology, Energy Laboratory, Cambridge, Mass.

Beggs, J., and S. Strong, 1982, "Cake Slicing and Revealed Government Preferences," Bell Journal of Economics 13(2).

Carrick, P.M., 1988, "New Evidence on Government Efficiency," Journal of Policy Analysis and Management 7(3).

Chamberlin, J.R., 1987, "Privatization as Institutional Choice," Journal of Policy Analysis and Management 6(4).

Dana, J.D., Jr., and K. Spier, 1994, "Designing a Private Industry," Journal of Public Economics 53.

Hilke, J.C., 1992, Competition in Government-Financed Services, Quorum Books, New York, N.Y.

Leitzel, J., 1992, “Competition in Procurement,” Policy Sciences 25:43-56.

Linowes, D.F., et al., 1988, Privatization: Toward More Effective Government, Report of the President's Commission on Privatization, Washington, D.C.

McFadden, D., 1975, "The Revealed Preferences of a Government Bureaucracy: Theory," Bell Journal of Economics 6(2).

McFadden, D., 1976, "The Revealed Preferences of a Government Bureaucracy: Empirical Evidence," Bell Journal of Economics 7(1).

Morgan, D.R., 1992, "The Pitfalls of Privatization: Contracting without Competition," American Review of Public Administration 22(4).

Oum, T.H., 1979, "A Warning on the Use of Linear Logit Models in Transport Mode Choice Studies," Bell Journal of Economics $10(1)$. 
Pack, J.R., 1987, "Privatization of Public-Sector Services in Theory and Practice," Journal of Policy Analysis and Management 6(4).

Pilling, D.L., 1989, Competition in Defense Procurement, The Brookings Institution, Washington, D.C.

Poole, R.W., Jr., and P. Fixler, Jr., 1987, "Privatization of Public-Sector Services in Practice: Experience and Potential," Journal of Policy Analysis and Management 6(4).

Poole, R.W., Jr., 1988, "The Limits of Privatization," in M. Walker (ed.), Privatization: Tactics and Techniques, Fraser Institute, Vancouver, B.C.

Rose, R., 1989, "Privatization as a Problem of Satisfising and Dissatisfising," American Review of Public Administration 19(2).

Sappington, D.E.M., and J. Stiglitz, 1987, "Privatization, Information, and Incentives," Journal of Policy Analysis and Management 6(4).

Seshadri, S., et al., 1991, "Multiple Source Procurement Competitions," Marketing Science 10(3).

Uttley, M., and N. Harper, 1993, "The Political Economy of Competitive Tendering," in T. Clarke and C. Pitelis (eds.), The Political Economy of Privatization, Routledge, London, United Kingdom.

Veljanovski, C., 1989, "Privatisation: Monopoly Money or Competition?" in C. Veljanovski (ed.), Privatisation and Competition: A Market Prospectus, Institute of Economic Affairs, Hobart, London, United Kingdom.

Vickers, J., and G. Yarrow, 1988, Privatization: An Economic Analysis, MIT Press, Cambridge, Mass. 